\title{
Comparative Study of Seismic Behaviour of High Rise Building with and Without Use of Fluid Viscous Damper Using E-Tabs
}

\author{
Milton Fernandes ${ }^{1}$, Swane Rodrigues ${ }^{2}$, Suraj Sharma ${ }^{3}$, Smit Raut ${ }^{4}$, \\ Mr. Shreeshail Heggond 5 \\ ${ }^{1234}$ UG Students, Department of Civil Engineering, St John College of Engineering \& Management, Palghar \\ ${ }^{5}$ Assistant Professor, Department of Civil Engineering, St John College of Engineering \& Management, Palghar
}

Received on: 6 May,2021 Revised on: 1 June, $2021 \quad$ Published on: 3 June,2021

\begin{abstract}
High rise building construction is adopted everywhere as we have sophisticated designing software's, engineers and also due to advancement in the field on engineering and technology. As the structure height increases its response to seismic and wind loading also increases. Codes suggest that the forces and displacements of a structure are directly proportional to its height.

A lot of research work is going on for reduction in responses during extreme loading condition due to wind and earthquake. Passive control devices like various types of dampers come very handy as they can be easily installed, requires no operation cost and are easily replaceable. These devices become active only when loading is applied. In this project we are going to study $\&$ discuss the reduction in response of a G+25 RCC commercial building when viscous dampers are used considering seismic loading and wind loading. Buildings with high ratio of its height to plan area will generate higher overturning moments while buildings with large plan areas may not act as expected due to differences in ground behavior (differential ground settlement) which are not always predictable. Torsion can be of great concern because of the eccentricity in the building layout which is not taken into consideration by the architects. Best type of bracing configuration, its location and comparison of dampers is to be studied. The analysis is done on ETABS 2019 and special emphasis is laid on reduction of displacement and storey drift.
\end{abstract}

Keywords- Dynamic Analysis, Seismic Performance, Viscous Dampers

\section{I -INTRODUCTION}

$\mathbf{D}_{\text {arthquake is the important term that comes to mind }}$ while designing any multi storey building. This earthquake are one of the most disastrous of natural criteria, This earthquake is known as 'Along fault plane the vibration and shaking takes place at the earth surface due to underground ground motion. There is a huge loss of life, property and many essential services. For this we have to take care while constructing the building, the structure should be an earthquake resistant. The earthquake resistant structures are the structures which can resist the largest earthquake that can possibly occur in particular area as per the standard codes. The structure should be having a good building configuration than it is an earth quake resistant structure it should be having better lateral stiffness, ductility, lateral strength, stability and integrity. The structure to be made earthquake resistant many technologies are developed in that seismic control devices are now more widely used in buildings.

Mainly there are three types of structural control systems, they are active energy dissipation system, semi active energy dissipation system, and passive energy 


\section{International Journal of Innovations in Engineering and Science, www.ijies.net}

dissipation system. For the seismic effects the passive energy systems are used. Damping may be defined as the process by which the free vibration of a vibrating body decreases in the amplitude. The range of damping is depending on the different types of materials used in construction, construction type and also the nonstructural elements. Measuring of damping done through critical damping. Dampers are placed in a structure to absorb the energy developed and lesser the shaking of the structure and reduction in the damage of the building.

Seismic control devices are Dampers During earthquake ground motion high magnitude energy is developed that develop a forces on building if the building is free of damping its stiffness is less and vibration in the structure is more, or else the structure is damped it increases the stiffness of the building as of the vibration reduces. Among various passive energy dissipating devices Fluid viscous dampers are more widely used in buildings. Fluid viscous dampers are enhance the performance of the building.

\section{A. Fluid viscous damper}

Fluid viscous dampers are one of the passive energy vanishing devices, for controlling vibration caused in structure and mechanical systems. In military and aerospace industry they use extensively these type of dampers from past years now a days these are used in the buildings to control the vibrations caused by wind and earthquakes. One of the greatest unique capacity of the dampers is it will together decreases both the stress and deflection within the structure subjected to transient. This is because the dampers vary its force only with the velocity, due to flexing of the structure the response that is permanently out of phases with the stresses. To vanishes the energy in the building these dampers are used because these dampers are velocity dependent. To reduce the responses in the building these effective damping should be done by using these type of dampers. FVDs are frequency independent devices without a stiffness component.

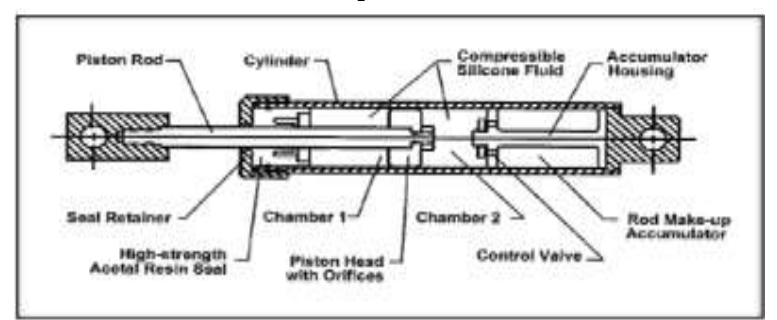

Fig 1: Longitudinal section of Fluid viscous damper

The figure shows in which dampers is in mid stroke position. The main pressure chamber is called cylinder, it consists full of fluid inside .It including the volume on both sides of piston. Piston head is connected with the piston rod. Clevis is present at the left hand side of the piston rod to attach the structure. These piston rod, piston head and clevis act as a single unit during dynamic phase they all move as one component and other components remains stationary. The fluid present in the cylinder is compress able viscous fluid silicone oil which is stable for heat, toxic free, inflammable and also environmental friendly.

\section{B. Damping characteristics}

The operation of FVD is happens when structure moves and it will add a resisting force and they do not add any stiffness to structure and do not carry any load. As a request we can add stiffness to the dampers. In FVDs the pressure is developed when a piston move back and forth. The orifice which is custom designed with piston develop and optimized relationship that produce this pressure that varies with velocity. Higher the velocity, higher the will be the resisting force .This relationship is represented by a equation.

Damping force $=$ Damping constant $\mathrm{x}$ velocity $\alpha$ $\mathrm{F} \mathrm{D}=\mathrm{C} \times \mathrm{V} \alpha$

$\alpha$ is the damping exponent. The value of $\alpha$ a very important role in magnitude of damping force .The damper with $\alpha$ value 1 then its is a linear damper in this case as per above equation the damper force is proportional to the velocity. As per practical application the value of $\alpha$ greater than 1 not still in practice.

The value of damping coefficient varies from the 0.2 to 2.0 depending on the specific application. In some cases it varies with a range of 0.3 to 1.0 . Value of $\alpha$ is very important for a present day structure design with seismic characteristics with a range of 0.3 to 0.5 is common.

There are many configurations are available for arrangement of dampers in a structural frame which can avoid significant functional and architectural compromises. The main point is considered is that the damper should be properly connected to points in the structure and act effectively when there is a motion due to sway of building. One of the simplest method to apply distributed damping to the structure the diagonal bracing method is most common to be used. 


\section{International Journal of Innovations in Engineering and Science, www.ijies.net}

\section{II- OBJECTIVES}

The following objectives are considered in the present studies

1. To know the response of a multi-storey buildings for a seismic activity a rectangular plan with rectangular column and beam sections are considered.

2. Comparison is made for a building with and without Fluid viscous dampers using both equivalent static method and response spectrum method.

3. To check the reduction in the various storey responses (Displacement, Storey shear, storey drift, modal periods and frequencies)

\section{III- METHODOLOGY}

1. In this present study, the ETABs 2019 abbreviated as "Extended Three-dimensional Analysis of Building system" software is used for modelling as well as analysis of the structure.

2. The symmetrical plan of reinforced concrete structure having 25 -story is considered.

3.The structure without damper is modelled and analysed in ETABs 2019. The model is assigned the class of gravity loads.

4. First the Earthquake loads as per IS1893-2002, Part1 are applied for structure located in zone 3. And dynamic analyses i.e. Response spectrum method is carried out for $5 \%$ damping and scale factor considered as per IS code in both $\mathrm{X}$ and $\mathrm{Y}$ directions.

5. To control the seismic response of the structure and to absorb or to transfer the lateral loads of the structure, the viscous damper is provided. The viscous damper is modelled in the ETABs software. And the parameters like displacement, storey drift and storey shears are studied and will be presented in the report.

\section{A. Methods of analysis}

There are many methods are available for the seismic analysis of a selected building to find out the forces developed in structure due to seismic activity. Mainly analysis is done on the basis of model of structure selected, materials used in the structure and also on the external inputs.
I. Equivalent static method is also called as equivalent lateral force method. Seismic analysis on a building is done on a assumption of the horizontal force is similar to the dynamic loading, In the method periods and shape of higher mode of vibration are not required so the effort for the analysis is less, except for the fundamental period. The base shear is calculated depends on the mass of structure, its fundamental periods of vibration and shapes. Firstly the base shear is calculated for a entire structure then along the height of building distribution is done. At each floor level the lateral force obtained are distributed to each structural element. This method is usually adopted for a low to medium height building.

II. Response spectrum method is also called as a modal method or mode superposition method. This method is used in a structure where the modes will affect the response of structure other than the fundamental one mainly this method used for a dynamic analysis of a building which are asymmetrical in plan or irregularity in areas. In case of multi storied buildings to find the forces and displacements caused due to medium range earthquake motion this method is used for analysis.

In this method directly from the earthquake design spectrum the peak response of a building is obtained during an earthquake ground motion. Peak responses obtained in this method are quite precise with the structural design application. In this method multiple mode of response are considered. Based on modal frequency and modal mass the individual mode response is read from the response spectrum.

\section{MODELLING AND ANALYSIS}

A 25 story moment resisting residential building was designed without any basement with plan dimension $25.61 \mathrm{~m}$ by $14.92 \mathrm{~m}$ (The total height of the building is $75 \mathrm{~m}$ and typical floor to floor height is $3 \mathrm{~m}$. The building is modelled symmetrically to avoid torsion effects. The inherent damping of the frame is considered $5 \%$. The frames have been modelled as rigid frames. All restrains that have been modelled are assumed to be fixed. Dead and live loads were assigned to the shell elements of the structure according to IS code. The compressible soil condition was not considered and the entire building was supported by fixed foundation.

\section{A. Description of building model}

Table 1- Description of building model 


\section{International Journal of Innovations in Engineering and Science, www.ijies.net}

\begin{tabular}{|l|l|}
\hline Structural Part & Dimensions \\
\hline Type of Building & Commercial Office Building \\
\hline Location of Building & Mumbai \\
\hline Plan dimensions & $25.61 \mathrm{~m}$ x 14.92m \\
\hline Numbers of floors & 25 \\
\hline Length in X- direction & $25.61 \mathrm{~m}$ \\
\hline Length in Y-direction & $14.92 \mathrm{~m}$ \\
\hline Floor to Floor height & $3 \mathrm{~m}$ \\
\hline Total height of building & $75 \mathrm{~m}$ \\
\hline Slab thickness & $150 \mathrm{~mm}$ \\
\hline Column size & Column 500x300 (1217) \\
\hline Beam size & Column 500x500 (2) \\
\hline Zone & Beam 450x300 (1697) \\
\hline Seismic Intensity & Beam 500x350 (3) \\
\hline Importance factor(I) & Beam 600x400 (1) \\
\hline Response Reduction Factor (R) & Moderate \\
\hline Soil type & 1.2 \\
\hline Grade of concrete(Beam) & TYPE III (Soft Soil) \\
\hline Gradeof concrete(Column) & M-40 \\
\hline Grade of concrete(Slab) & M-40 \\
\hline Reinforcement & HYSD500 \\
\hline Unit weight of concrete & Mild250 \\
\hline & $40 \mathrm{kN} / \mathrm{m}^{2}$ \\
\hline
\end{tabular}

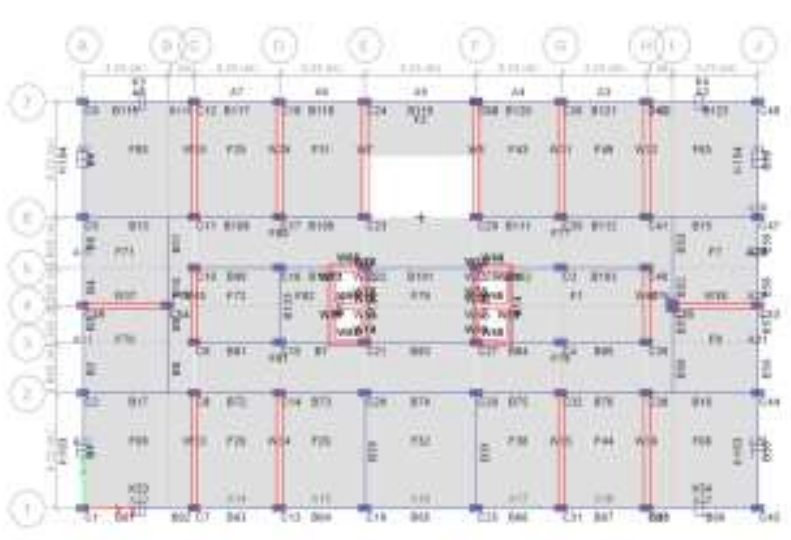

Fig. 1- Plan view of building with FVD in ETABS

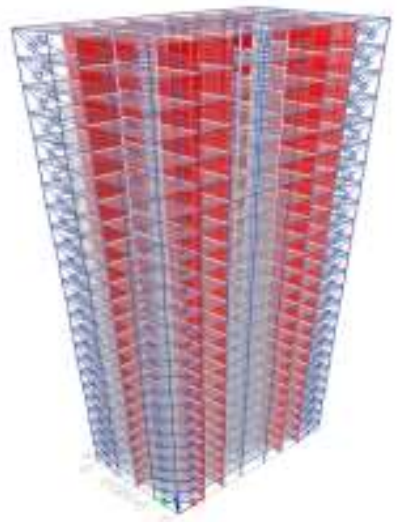

Fig.2-3D View of Model In Etabs



Fig.3- FVD at exterior corner Elevation in YZ plane

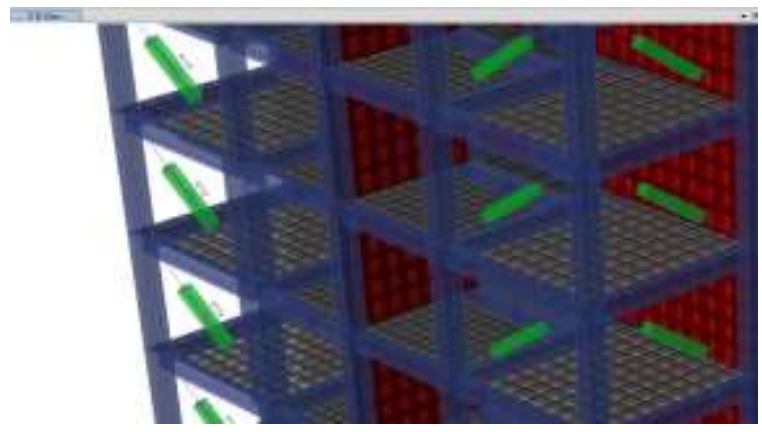

Fig.4- FVD at exterior corner extrude view

\section{V- RESULT}

Modelling of building is done with the all the defined loads as per the code provisions. Then the analysis of the structure is done with both Equivalent static method and Response spectrum method. After the analysis various storey responses are compared and comment should be made on those results. A storey response includes storey displacement storey drifts, storey shear and Modal time and frequencies are considered and compared.

\section{A. Storey displacement}

Storey displacement is a main storey response that get reduced after adding dampers to the structures. 
International Journal of Innovations in Engineering and Science, www.ijies.net

For a $\mathrm{G}+25$ storey building with and without viscous dampers the displacement value obtained for both equivalent static method and response spectrum method along both $\mathrm{x}$ and $\mathrm{y}$ direction

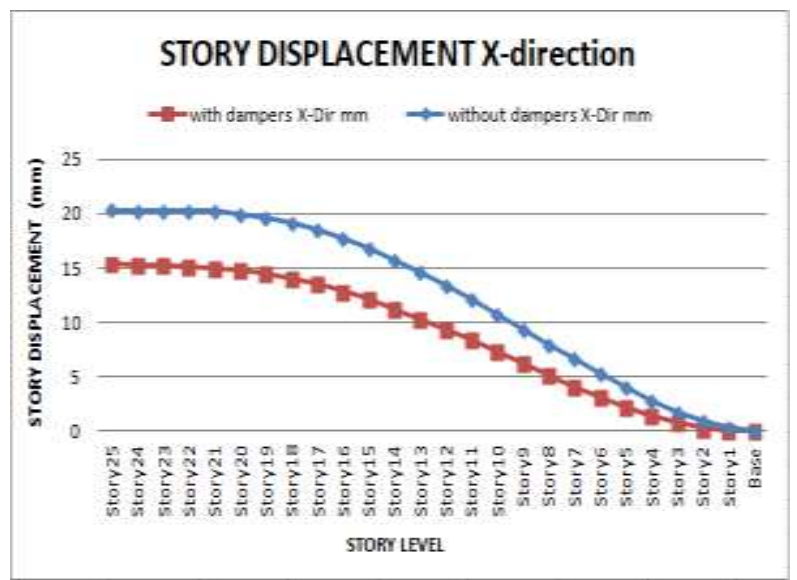

Graph 1: Storey displacement in $x$ direction for Static method

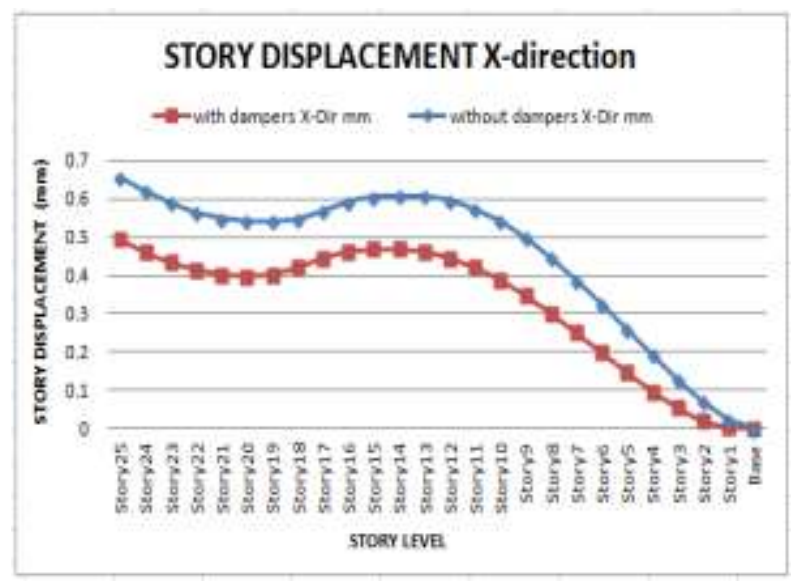

Graph 2: Storey displacement in $x$ direction for response spectrum method

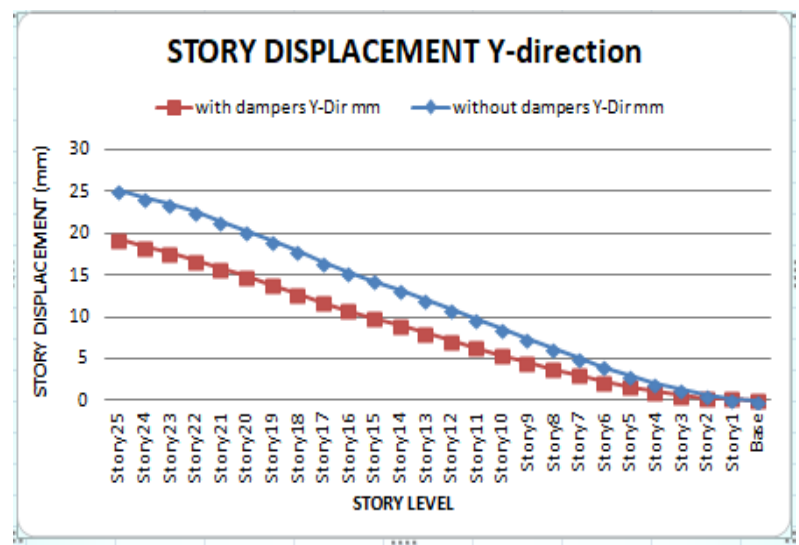

Graph 3: Storey displacement in Y direction for Static method

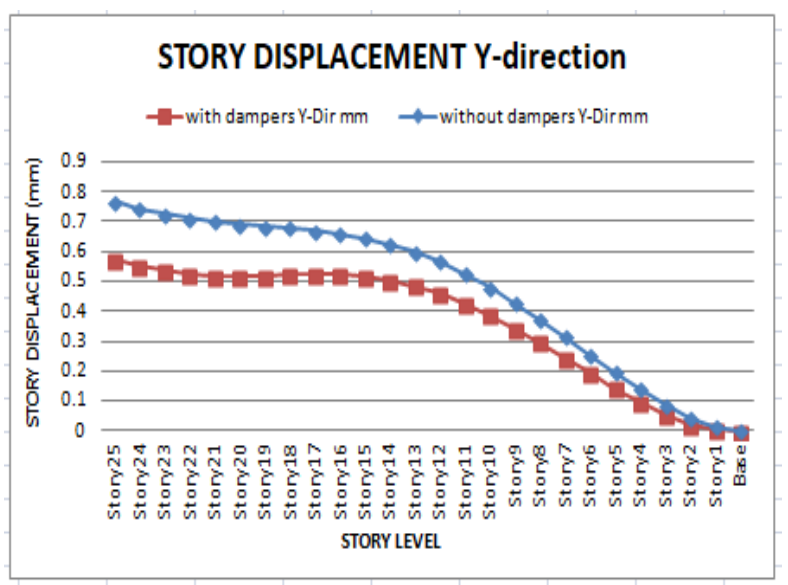

Graph4: Storey displacement in Y direction for response spectrum method

Table 2-Displacement Table

\begin{tabular}{|l|c|c|c|c|c|}
\hline \multirow{2}{*}{ Story } & \multirow{2}{*}{ Elevation } & \multicolumn{3}{|c|}{ Story Displacement } \\
\cline { 3 - 6 } & & \multicolumn{2}{|c|}{ X-Direction } & \multicolumn{2}{c|}{ Y-Direction } \\
\cline { 3 - 6 } & & Without & $\begin{array}{c}\text { With } \\
\text { Damper }\end{array}$ & $\begin{array}{c}\text { Without } \\
\text { Damper }\end{array}$ & $\begin{array}{c}\text { With } \\
\text { Damper }\end{array}$ \\
\hline Story25 & 75 & 20.361 & 15.39 & 25.278 & 19.345 \\
\hline tory24 & 72 & 20.252 & 15.311 & 24.258 & 18.341 \\
\hline tory23 & 69 & 20.307 & 15.269 & 23.485 & 17.62 \\
\hline tory22 & 66 & 20.333 & 15.197 & 22.511 & 16.766 \\
\hline Story21 & 63 & 20.255 & 15.059 & 21.443 & 15.832 \\
\hline tory20 & 60 & 20.045 & 14.834 & 20.301 & 14.841 \\
\hline tory19 & 57 & 19.692 & 14.509 & 19.099 & 13.811 \\
\hline Story18 & 54 & 19.191 & 14.076 & 17.853 & 12.755 \\
\hline Story17 & 51 & 18.542 & 13.535 & 16.571 & 11.685 \\
\hline Story16 & 48 & 17.754 & 12.889 & 15.439 & 10.736 \\
\hline tory15 & 45 & 16.837 & 12.143 & 14.317 & 9.845 \\
\hline Story14 & 42 & 15.804 & 11.307 & 13.179 & 8.955 \\
\hline Story13 & 39 & 14.668 & 10.392 & 12.027 & 8.066 \\
\hline Story12 & 36 & 13.446 & 9.412 & 10.864 & 7.182 \\
\hline tory11 & 33 & 12.155 & 8.384 & 9.694 & 6.306 \\
\hline Story10 & 30 & 10.813 & 7.322 & 8.525 & 5.443 \\
\hline Story9 & 27 & 9.439 & 6.248 & 7.363 & 4.6 \\
\hline Story8 & 24 & 8.054 & 5.18 & 6.219 & 3.784 \\
\hline Story7 & 21 & 6.68 & 4.141 & 5.104 & 3.007 \\
\hline Story6 & 18 & 5.341 & 3.153 & 4.035 & 2.279 \\
\hline Story5 & 15 & 4.064 & 2.244 & 3.03 & 1.616 \\
\hline Story4 & 12 & 2.88 & 1.44 & 2.113 & 1.035 \\
\hline Story3 & 9 & 1.827 & 0.774 & 1.311 & 0.556 \\
\hline Story2 & 6 & 0.951 & 0.279 & 0.661 & 0.24 \\
\hline Story1 & 3 & 0.316 & 0.064 & 0.219 & 0.227 \\
\hline Base & 0 & 0 & 0 & 0 & 0 \\
\hline
\end{tabular}




\section{International Journal of Innovations in Engineering and Science, www.ijies.net}

By observing all the above results the placing of FVD in the building will reduces the storey displacement due to seismic loads effectively in both directions. From the results of storey displacements bare framed building without a FVD having maximum displacement when compared with a building with FVD

\section{B. Storey drifts}

The inter storey drifts values for the considered building along $\mathrm{x}$ and $\mathrm{y}$ direction are tabulated below. As per IS 1893:2016 for a storey with minimum assigned lateral force, having partial load factor 1.0 the storey drift value does not exceed 0.004 times the height of a storey.

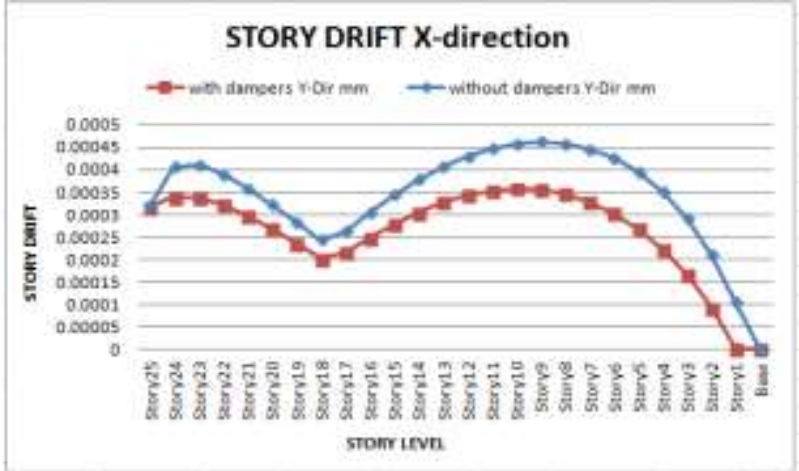

Graph 5: Storey drift in $x$ direction for Static method

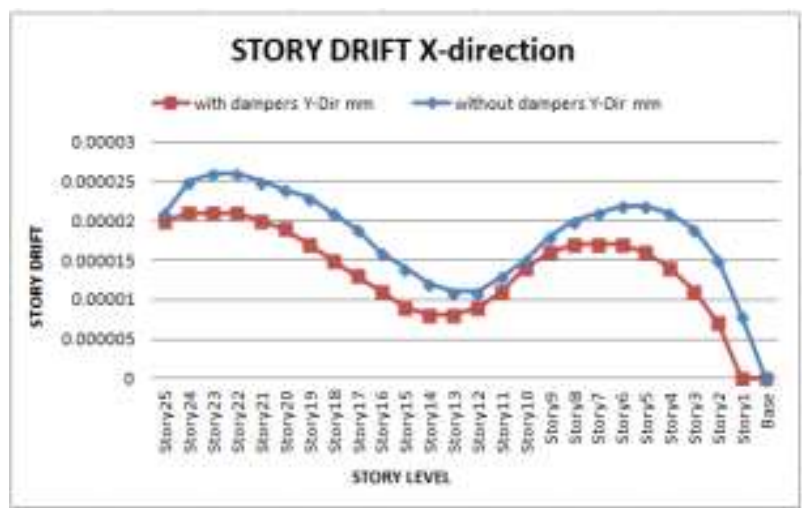

Graph 6: Storey drift in x direction for response spectrum method

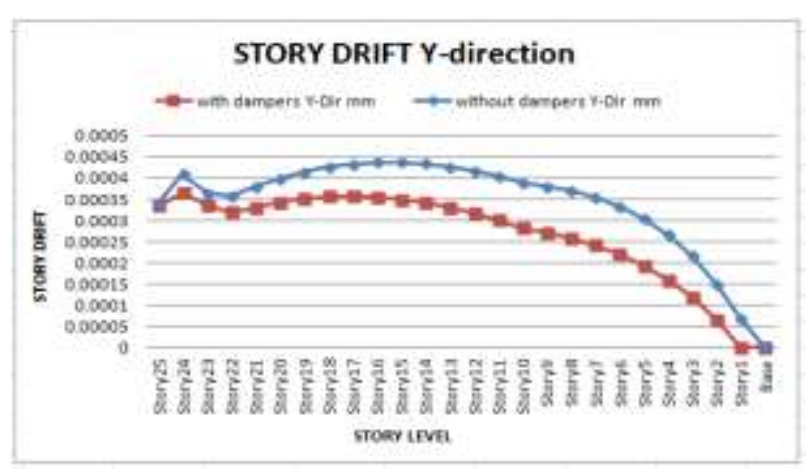

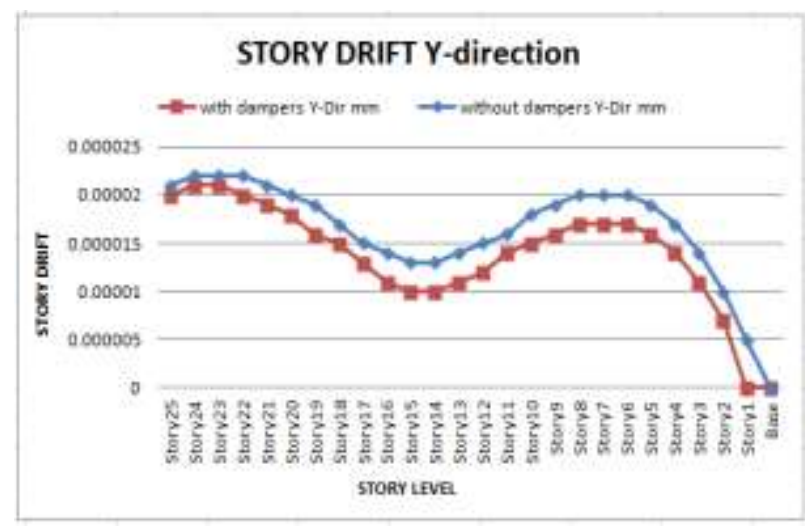

Graph 8: Storey drift in Y direction for response spectrum method

Table 3 - Drift Table

\begin{tabular}{|c|c|c|c|c|c|}
\hline \multirow{3}{*}{ STORY } & \multirow{3}{*}{ LEEVATION } & \multicolumn{4}{|c|}{ STORY DRIFT } \\
\hline & & \multicolumn{2}{|c|}{ X-DIRECTION } & \multicolumn{2}{|c|}{ Y-DIRECTION } \\
\hline & & $\begin{array}{l}\text { WITHOUT } \\
\text { DAMPER }\end{array}$ & $\begin{array}{c}\text { WITH } \\
\text { DAMPER }\end{array}$ & $\begin{array}{l}\text { WITHOUT } \\
\text { DAMPER }\end{array}$ & $\begin{array}{c}\text { WITH } \\
\text { DAMPER }\end{array}$ \\
\hline Story25 & 75 & 0.00032 & 0.000317 & 0.00034 & 0.000335 \\
\hline Story24 & 72 & 0.000407 & 0.000339 & 0.00041 & 0.000366 \\
\hline Story23 & 69 & 0.000411 & 0.000337 & 0.000366 & 0.000336 \\
\hline Story22 & 66 & 0.00039 & 0.000322 & 0.000359 & 0.00032 \\
\hline Story21 & 63 & 0.000359 & 0.000298 & 0.000381 & 0.00033 \\
\hline Story20 & 60 & 0.000323 & 0.000269 & 0.0004 & 0.000343 \\
\hline Story 19 & 57 & 0.000284 & 0.000236 & 0.000416 & 0.000352 \\
\hline Story18 & 54 & 0.000245 & 0.000202 & 0.000427 & 0.000357 \\
\hline Story 17 & 51 & 0.000263 & 0.000216 & 0.000434 & 0.000358 \\
\hline Story 16 & 48 & 0.000306 & 0.000249 & 0.000438 & 0.000356 \\
\hline Story15 & 45 & 0.000344 & 0.000279 & 0.000438 & 0.00035 \\
\hline Story 14 & 42 & 0.000379 & 0.000305 & 0.000435 & 0.000342 \\
\hline Story13 & 39 & 0.000407 & 0.000327 & 0.000428 & 0.000331 \\
\hline Story 12 & 36 & 0.00043 & 0.000343 & 0.000419 & 0.000317 \\
\hline Story 11 & 0 & 0.000447 & 0.000354 & 0.000406 & 0.000301 \\
\hline Story 10 & 30 & 0.000458 & 0.000358 & 0.000391 & 0.000282 \\
\hline Story9 & 27 & 0.000462 & 0.000356 & 0.000381 & 0.000272 \\
\hline Story8 & 24 & 0.000458 & 0.000346 & 0.000371 & 0.000259 \\
\hline Story7 & 21 & 0.000446 & 0.000329 & 0.000356 & 0.000242 \\
\hline Story6 & 1 & 0.000426 & 0.000303 & 0.000335 & 0.000221 \\
\hline Story5 & 15 & 0.000395 & 0.000268 & 0.000306 & 0.000194 \\
\hline Story4 & 12 & 0.000351 & 0.000222 & 0.000267 & 0.00016 \\
\hline Story3 & 9 & 0.000292 & 0.000165 & 0.000217 & 0.000118 \\
\hline Story2 & 6 & 0.000211 & $9.30 \mathrm{E}-05$ & 0.000151 & $6.70 \mathrm{E}-05$ \\
\hline Story1 & 3 & 0.000105 & 0 & $6.90 \mathrm{E}-05$ & 0 \\
\hline Base & 0 & 0 & 0 & 0 & 0 \\
\hline
\end{tabular}

Graph 7: Storey drift in Y direction for Static method 


\section{International Journal of Innovations in Engineering and Science, www.ijies.net}

From the above observation the storey drift will be max for a building without damper as compared to building with damper. The max drift value for any building does not exceed the limited value specified by the IS standards. By placing the dampers in the building will reduce the drift value.

\section{Storey shear}

The storey shear is the shear value computed from the adding of design lateral forces at the levels above the storey consideration of the structure. Usually the storey shear value is maximum at the lower stories and minimum at the higher stories.

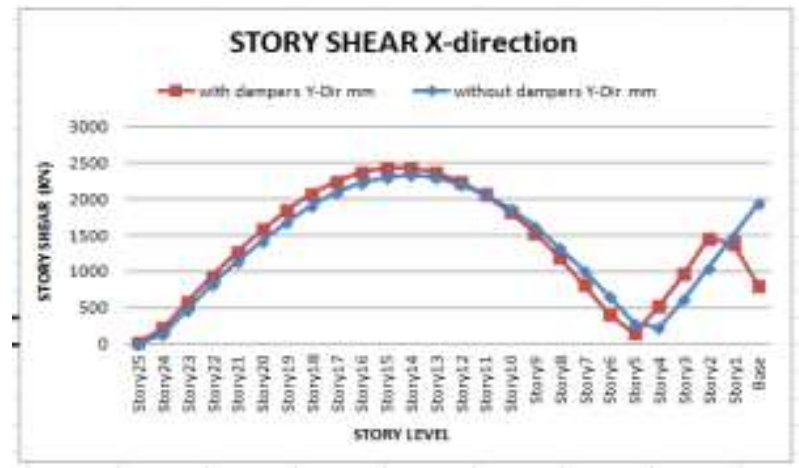

Graph 9: Storey shear in x direction for Static method

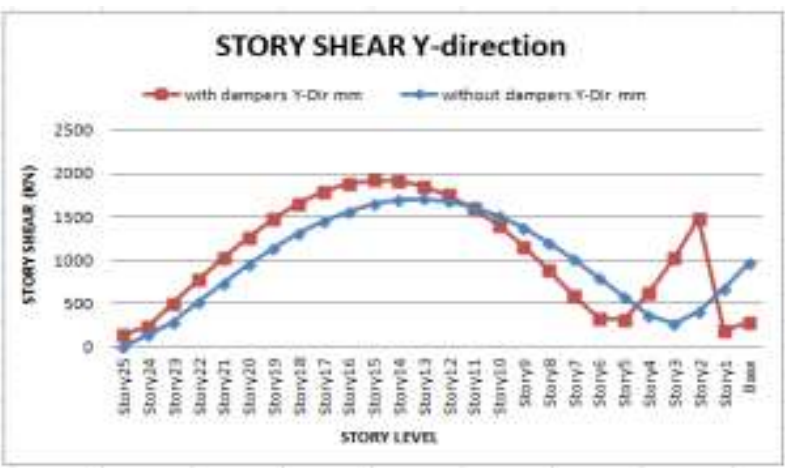

Graph 10: Storey shear in Y direction for Static method

From the above observation we seen that the shear value is increases towards the bottom stories in case of without damped building, But in case of damped building the shear value is increases towards the upper stories. By adding dampers to the building the max shear value will be reduced in a building. Shear at the base will be reduced in damped building.

\section{Modal periods and frequencies}

During earthquake or wind, all modes are excited in different manner .Depends on the spatial distribution and frequency content of the load the length of dynamic loading excites the modes of vibration. In this study 12 modes are considered and their time period and frequencies.

Table 3.12- Modal Participating Mass Ratos (Part 1 of 2 )

\begin{tabular}{|c|c|c|c|c|c|c|c|c|c|c|}
\hline Case & Mose & $\begin{array}{l}\text { Period } \\
\text { ses: }\end{array}$ & EX & UY & UZ & SumUX & Sumur & SumUz & $R X$ & Rr \\
\hline Mods & 1 & 1821 & 20014 & 2235E-08 & 0 & 0.0534 & $22265: 58$ & 2 & $Q 41 E-07$ & 0,0532 \\
\hline Mata: & 2 & का & sas:8 & B. WSE-U? & 0 & 0.7442 & 284650 & 0 & 0 & 00044 \\
\hline Hotal & 2 & 8571 & a bese of & 07204 & 0 & 0.742 & 2.7254 & 9 & 0,0006 & 1 23EE 05 \\
\hline Mata & 4 & 0.507 & 00004 & 0.0602 & 0 & 0.7487 & 2728 & 0 & 1.759E-09 & $0.05=5$ \\
\hline Mota: & 5 & 2.352 & Doset & 0 & 0 & 0.7551 & cras & a & 0 & 0358 \\
\hline Moda & $t$ & 1277 & 0,008 & ISTEAC & D & 0.231 & 07209 & 0 & 000001 & 0015 \\
\hline Mata & 7 & 0.213 & 4 coset- 06 & 00053 & 0 & 07231 & $: 725$ & 0 & 0.54 & 1.44EE- -8 \\
\hline Usta! & 8 & 2.88 & 20078 & 0 & 0 & 0.3407 & 0.7258 & 0 & 4799E- 08 . & 0014 \\
\hline Motal & 8 & $213 \mathrm{~A}$ & 20012 & 2.7HE-OA & $D$ & D.345 & 27nst & a & 1. OLEE 04 & 000000 \\
\hline Modal & 18 & 2133 & 0.0585 & TBSE 007 & D & 0.8481 & 2725 & a & 0 & 60004 \\
\hline Uata: & 11 & Q.114 & 0 & 0.504 & 0 & 0.5451 & 0.3244 & 0 & 0.0006 & 0 \\
\hline Uotal & 12 & 0.098 & 0.0248 & 0 & 0 & 0.8737 & 8.8244 & 0 & 0 & 000109 \\
\hline
\end{tabular}

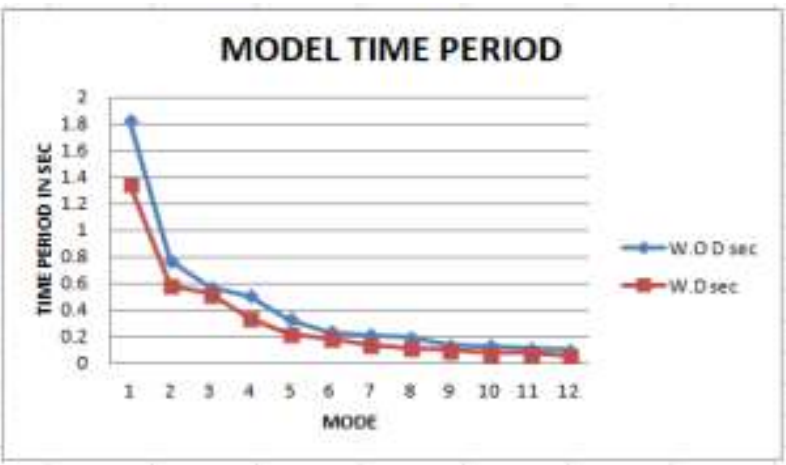

Graph 11: Modal periods

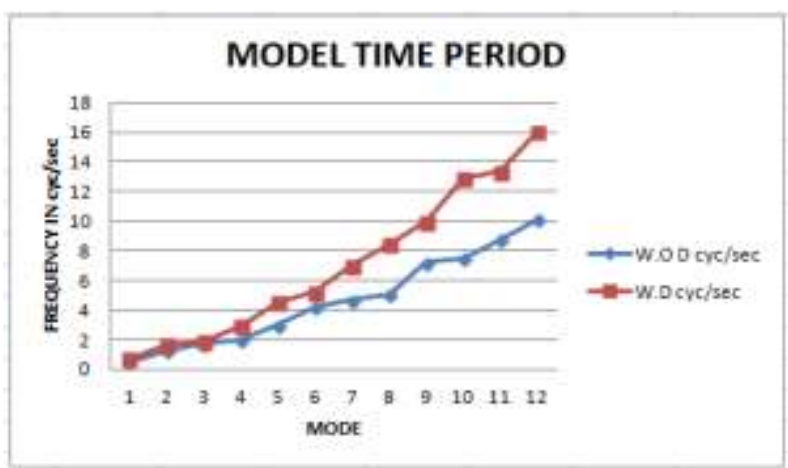

Graph 12: Modal frequency

The time period for a without damping building is more as compared to the damping building. The time period is inversely proportional to the frequency of the structure. So the natural frequency of the damped building is more compared to the building without damper. As the frequency of the structure increases the stiffeness of structure is also increases because stiffness is directly 


\section{International Journal of Innovations in Engineering and Science, www.ijies.net}

proportional to the frequency. For a higher elevation building the frequency is more because of more mass

\section{VI- CONCLUSION}

For a G+25 storey symmetric building the earthquake analysis is carried out by equivalent static method and response spectrum method and following are the observation made and concluded from the present study, they are

The main objective of this Project is to determine how dampers and its configuration could improve the performance of buildings or structures so as to be satisfactory for the higher seismic zones

In this project, viscous dampers are to be used to reduce the seismic effect of the structure which are subjected to the earthquake load. The frames (with and without viscous damper) is modeled according to the properties of the structure

The seismic behavior of the Reinforced Concrete structure is judged by observing the parameters such as:

\section{Displacement:}

Storey displacement in a regular building not having dampers will have a maximum displacement value when compared to a building provided with damper. By the addition of dampers to the structures will drastically reduce the displacement value and increase the stability of the structure. As the height of the building increases the displacement value also increases so in order to reduce storey displacement dampers are used

\section{Story Drift:}

Storey drift value for a regular building will be more when compared to the building with damper. By adding damper to the structure the drift value will be reduced and the max drift value of a building does not exceed the limited value specified by the Indian standards

\section{Story Shear ( $k N$ )}

Storey shear value for a building without damper will be maximum at the base and for a building with damper will have a max shear value at the top storey, but the shear value of a undammed building will be more compared to the damped building

\section{Time periods}

For 12 modes for a undammed building is more due to which frequency are reduces. But for a damped building time period are less frequency is more. Observed that $75 \%$ of frequency increases so that stiffness of building increases effectively by using FVD 500 dampers at the exterior corners of the building

\section{REFERENCES}

[1] jreshwari Umachagi, Katta Venkataramana, G. R. Reddy, Rajeev Verma, "Applications of Dampers for Vibration Control Of Structures: An Overview" International Journal of Research in Engineering and Technology, Nov2013.

[2] Liya Mathew \& C. Prabha, "Effect of Fluid Viscous Dampers in Multi-Storeyed Buildings", International Journal of Research in Engineering \& Technology, Vol. 2, Issue 9, Sep 2014, 55- 60.

[3] Su Myat Aye, Dr. Kyaw Moe Aung, "Comparative Study on Seismic Response of RC Structure Using Viscous Dampers and Viscoelastic Dampers", International Journal Of Scientific Engineering And Technology Research, Vol.03, Issue.08, May-2014, Pages:1468- 1478

[4] Douglas Taylor, President, Taylor Devices Inc., "History, Design and Application of Fluid Dampers in Structural engineering"

[5] The manufacturer of the Viscous Damper product Taylor Devices Inc., India.

[6] Mohammad Javad Dehghan, Mostafa Soleymannejad, "Improving Seismic Performance of Concrete Buildings with Special Moment Frames Using Viscous Damper", InternationalJournal of Modern Engineering Research, Vol. 5, Issue. 7, July 2015.

[7] Yuvraj Bisht, Saraswati Setia, "Seismic Behaviour Of A Soft Storey Building With \& Without Viscous Dampers", International Journal of Engineering Research and Applications (IJERA) ISSN: 2248-9622, pg. no 10-15

[8] The manufacturer of the Viscous Damper product Taylor Devices Inc., India.

[9] Lee. D., and Taylor. D. P, "Viscous damper development and future trends", Struct., Des., Tall Build, vol-10(5), 2001, pg.no-(311-320).

[10] Alireza Heysami, "Types of Dampers and their Seismic Performance during an Earthquake", CurrentWorld Environment, Vol. 10(Special Issue 1), 1002-1015 (2015).

[11] Dharmesh Chandnani, Riddhi Joshi, Kumarpal Trivedi, "Characteristics \& Applications of Different Types of Dampers as Seismic Energy Dissipater”, International 
Vol. 6, No. 5, 2021, PP. 22 -30

International Journal of Innovations in Engineering and Science, www.ijies.net

Journal of Computer Science and Network, Volume 5, Issue 2, April 2016 pg.no (369-372).

[12] Jenn-Shin Hwang, Chun-Hsiang Tsai, Shiang-Jung Wang, Yin-Nan Huang, "Experimental study of RC building structures with supplemental viscous dampers and lightly reinforced walls", Engineering Structures, accepted 6 March 2006, pg.no (1-9), at 2006 Elsevier Ltd.

[13] Alessandra Aprile; Jose A. Inaudi/ and James M. Kelly, "evolutionary model of viscoelastic dampers for structural applications", journal of engineering mechanics, pp 551-560B. Samali, "Use of viscoelastic dampers in reducing wind- and earthquake- induced motion of building structures" Engineering Structures, Vol. 17, No. 9, pp. 639-654, 1995 